PARRISH, W., and IRwin, B. W. Data for X-ray analysis. Vol. I. Charts for solution of Bragg's equation (d versus $\Theta$ and $2 \Theta$. Eindhoven, Philips' Technical Library, 1953. $99 \mathrm{pp}$.

PÉRÈs, J. Méchanique gênérale. Paris, Masson, $1953.4+407$ pp. 2545 fr.

PICKERT, G. Analytische Geometrie. (Mathematik und ihre Anwendungen in Physik und Technik, Series A, vol. 24.) Leipzig, Geest and Portig, 1953. 10+398 pp. 26.00 DM.

Polubarinova-KočIna, P. YA. Teoriya dviそeniya gruntovyh vod. Moscow, Gosudarstvennoe Izdatel'stvo Tehniko-Teoreticeskoi Literatury, 1952. 676 pp. 13.85 rubles.

Probability tables for the analysis of extreme-value data. (National Bureau of Standards Applied Mathematics Series, no. 22.) Washington, Government Printing Office, 1953. $3+32$ pp. $\$ 0.25$.

Reno, F. V. See McShane, E. J.

Romig, H. G. 50-100 binomial tables. New York, Wiley, 1953. $27+172$ pp. $\$ 4.00$.

SAARNIO, U. Die Wohlordnung einer nichtabzählbaren Menge und die Lösung des Kontinuumproblems. (Abhandlungen der Gesellschaft für Logik und ihre Anwendungen, no. 1.) Helsinki, 1953. 59 pp.

SAGAN, H. See Funk, P.

Selig, F. See Funk, P.

SHaw, F. S. An introduction to relaxation methods. New York, Dover, 1953. 396 pp. $\$ 5.50$.

Singh, A. N. See Hobson, E. W.

Sominskiř, I. S. See FADDEEv, D. K.

SPenCER, D. C. On Green's operators. College Park, Md., The Institute for Fluid Dynamics and Applied Mathematics, University of Maryland, 1952. 1+23 pp. (mimeographed)

StruIK, D. J. Lectures on analytic and projective geometry. Cambridge, Addison-Wesley, 1953. $9+291$ pp. $\$ 6.50$.

Tables of normal probability functions $\left(1 /(2 \pi)^{1 / 2}\right) e^{-x^{2} / 2}$ and $\left(1 /(2 \pi)^{1 / 2}\right) \int_{-x}^{x} e^{-\alpha^{2} / 2} d \alpha$. (National Bureau of Standards Applied Mathematics Series, no. 23.) Washington, Government Printing Office, 1953. 9+344 pp. $\$ 2.75$.

Toraldo di Francia, G. Onde elettromagnetiche. Bologna, Zanichelli, 1953. 13+286 pp. 3000 lire.

vaN VeEN, H. J. Inleiding tot de nomographie. 2d printing. Groningen, Noordhoff, 1952. 197 pp. $12.50 \mathrm{fl}$.

ZweILIng, K. Grundlagen einer Theorie der biharmonischen Polynome. Berlin, Verlag Technik, $1952.8+130$ pp., 5 plates, 1 insert.

\title{
ERRATA, Volume 59
}

Melvin Henriksen, On the prime ideals of the ring of entire functions, p. 66, abstract 82.

Line 1 of the abstract: For "nonmaximal ideals" read "nonmaximal prime ideals."

Line 6 of the abstract: For "The class $P$ of all prime ideals" read "The class $P_{m}$ of all prime ideals $P . "$ 